\title{
GLACIOLOGICAL OBSERVATIONS ON THE ROSS ICE SHELF NEAR SCOTT BASE, ANTARGTICA*
}

\author{
By A. W. Stuart and C. Bull \\ (Institute of Polar Studies, The Ohio State University, Columbus, Ohio)
}

\begin{abstract}
On the Ross Ice Shelf near Scott Base the annual surface snow accumulation is about $18 \mathrm{~g} \cdot \mathrm{cm} .^{-2}$. The increase of firn density with depth is greater than normal, due to horizontal compaction. Where the bottom of the ice shelf has a density less than $0.8 \mathrm{~g} . \mathrm{cm} .^{-3}$ the shelf becomes brine-soaked by vertical infiltration. The bottom of the shelf is melting, at about $44 \mathrm{~g} . \mathrm{cm} .^{-2} \mathrm{yr} .^{-1}$ where the bottom is impermeable ice and $73 \mathrm{~g} . \mathrm{cm}^{-2} \mathrm{yr}^{-1}$ where the bottom is permeable firn. Surface velocities at 40 points within $30 \mathrm{~km}$. of Scott Base vary between 4 and $840 \mathrm{~m} . y r^{-1}$. From the pattern of velocities, ice thicknesses and surface features, a transition zone is delineated, separating the Ross Ice Shelf from the "McMurdo Ice Shelf",
\end{abstract}

RÉsumé. L'accumulation annuelle de la neige à la surface de l'Ice Shelf de Ross, près de Scott Base est d'environ $18 \mathrm{~g} \mathrm{~cm}^{-2}$. La compression horizontale cause une augmentation plus grande que la normale de la densité du névé avec la profondeur. Lorsque la partie infèrieure de l'Ice Shelf a une densité de moins de $0,8 \mathrm{~g} \mathrm{~cm}^{-3}$ la plate-forme est imprégnée de sel par infiltration verticale. La base de la plate-forme fond d'environ $44 \mathrm{~g} \mathrm{~cm}^{-2}$ par an lorsqu'elle est formée de glace imperméable et de $73 \mathrm{~g} \mathrm{~cm}^{-2}$ par an dans le cas de névé perméable. Les déplacements de la surface en 40 points distants jusqu'à $30 \mathrm{~km}$ de la Scott Base varient de 4 à $840 \mathrm{~m}$ par an. La distribution des vitesses, des épaisseurs de glace et des formes superficielles permettent d'établir un zône de transition entre l'Ice Shelf de Ross et l'Ice Shelf de McMurdo.

Zusammenfassung. Der jährliche Schneezuwachs auf dem Ross-Eisschelf beträgt in der Nähe der ScottStation etwa $18 \mathrm{~g} \mathrm{~cm}^{-2}$. Infolge horizontaler Zusammenpressung ist die Dichtezunahme des Firns mit der Tiefe grösser als normal. Wo die Unterseite des Schelfeises eine Dichte von weniger als $0,8 \mathrm{~g} \mathrm{~cm}^{-3} \mathrm{besitzt}$ sickert Salzwasser von unten in das Schelfeis ein. An der Unterseite schmilzt ungefähr $44 \mathrm{~g} \mathrm{~cm}^{-2}$, wenn das Eis undurchlässig ist, und ungefähr $73 \mathrm{~g} \mathrm{~cm}^{-2}$, wenn sie aus durchlässigem Firn besteht. Die Oberflächengeschwindigkeiten von 40 Punkten in einem Umkreis von $30 \mathrm{~km}$ von der Scott-Station liegen zwischen 4 und $840 \mathrm{~m}$ pro Jahr. Die Verteilung der Geschwindigkeiten, der Eisdicken und Oberflächenformen lässt eine Übergangszone abgrenzen, die den Ross-Eisschelf vom "McMurdo-Eisschelf" trennt.

\section{INTRODUGTION}

The work of the United States Antarctic Research Program party who wintered at Scott Base during 1959, preparing for the 1959-6o Victoria Land traverse, included glaciological observations on the part of the Ross Ice Shelf near Scott Base. Observations were made between January and September 1959 and in the month following the traverse party's return to Scott Base on io February 1960 .

Because no glaciological program for the winter had been formulated and the investigators were inexperienced, much time was spent in developing techniques. The observations were not distributed areally in the optimum manner and the data are incomplete, but this report illustrates some of the glaciological problems of the area and indicates the field work which is still required.

Most of the observations were made by A. W. Stuart, assisted by Mr. A. J. Heine of the New Zealand Geological Survey. Mr. Heine, in addition, measured the movement of the markers close to Scott Base and also assisted in the reduction of the data at this Institute.

\section{Physiographic Setting}

Scott Base (lat. $77^{\circ} 5^{\mathrm{I}^{\prime}}$ S., long. $166^{\circ} 45^{\prime}$ E.) is at Pram Point, at the south-eastern extremity of the Hut Point peninsula of Ross Island (Fig. I).

The Ross Ice Shelf occupies the approximately triangular area between the points lat. $78^{\circ} \mathrm{S}$., long. $164^{\circ} \mathrm{E}$., lat. $77^{\circ} \mathrm{S}$., long. $158^{\circ} \mathrm{W}$., and lat. $85^{\circ} \mathrm{S}$., long. $160^{\circ} \mathrm{W}$., although its northern limit, in McMurdo Sound and the Ross Sea, varies from year to year. In the

* Contribution No. I4, Institute of Polar Studies, The Ohio State University, Columbus, Ohio. 
north-west the northward flow of the ice shelf is hindered by Minna Bluff, Brown Peninsula and White, Black and Ross Islands.

It is convenient to divide the part of the Ross Ice Shelf north of Minna Bluff and west of long. $17 \mathrm{I}^{\circ} \mathrm{E}$. into three areas (Fig. 2): (i) the north-western margin of the main Ross Ice Shelf, from about long. $17 \mathrm{I}^{\circ} \mathrm{E}$. to roughly a line from station 89 to Cape Crozier, where the ice movement is northwards; (ii) a transition zone, bounded in the east by the line from station 89 to Cape Crozier and in the west by the line from the north end of White Island to



Fig. I. Map of the north-western part of the Ross Ice Shelf, showing location of outlying movement stations. (Based on New Zealand Lands and Survey Department map N.Z.M.S. I35)

Cape MacKay; and (iii) the area bounded in the east by the White Island-Cape MacKay line, on the south by White and Black Islands, and in the north and west by Ross Island and McMurdo Sound, where the ice movement is predominantly westwards. For this third area the name "McMurdo Ice Shelf" is used. Significant differences exist in the regime of the eastern and the western parts of the "McMurdo Ice Shelf"; most of the present observations and discussion refer to the eastern part. 


\section{Snow Accumulation on the Ice Shelf}

\section{Stake measurements}

In February, March and April i 959, stakes were erected at the points shown in Figures 3 and 4 , and the snow accumulation was measured monthly until October. A final measurement (of the surviving stakes) was made in February i 960 . Mean values for the snow accumulation in various areas are given in Figure 5 . Most of the accumulation occurred late in winter but

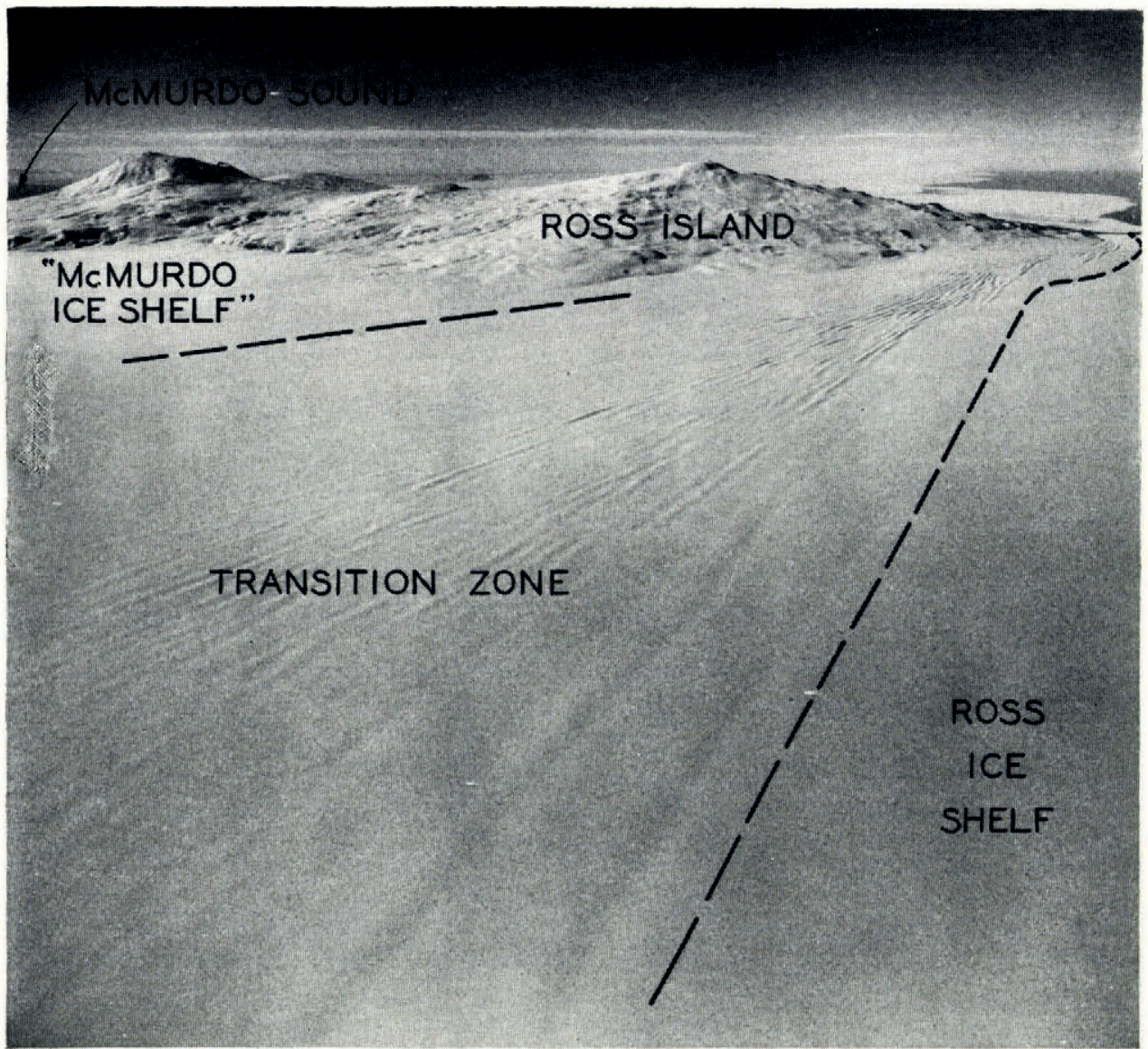

Fig. 2. Aerial photograph of Ross Island and part of the Ross Ice Shelf, looking northwards from above station 89. (Photograph 262 F-31 VX-6 USN $3 / 125$ December 1956 o626Z; courtesy of U.S. Navy)

little occurred in the summer. The accumulation varied significantly from one point to the next; Figure 6 shows the values at the individual stakes between Pram Point and White Island.

Many measurements of the density of the uppermost annual snow layer were made in February 1959 and February 1960. In both years the average was 0.39 g.cm. ${ }^{-3}$. Using this value, the mean accumulation at the so stakes in the strain line for February i 959-February I 960 was I 7.9 g.cm..$^{-2}$, and at the I I stakes between Pram Point and White Island for Io March I959-20 February I96o, I 3.6 g.cm. ${ }^{-2}$. 
Snow pit measurements

A pit $7 \mathrm{~m}$. deep was dug $5 \mathrm{~km}$. east of Scott Base (Fig. 4). The stratigraphy of the walls, interpreted in the standard way, gives the annual layering for the period I94I to I959. The stratigraphy of an $8 \mathrm{~m}$. core taken from the bottom of the pit to a total depth (below the ice shelf surface) of about $15 \mathrm{~m}$. is less reliably interpreted to cover the period I9I 3 to I 940 . For both periods, I $94^{1-59}$ and I 1 I $3-40$, the mean accumulation was $17 \cdot 6 \mathrm{~g} . \mathrm{cm}^{-2}$. Yearly values of the accumulation are given in Table I.

Table I. Interpretation of Stratigraphy in Walls of $7 \mathrm{~m}$. Pit (o-68o cm.) and in Core taken below the Pit Bottom

\begin{tabular}{|c|c|c|c|}
\hline rear & $\begin{array}{l}\text { Depth } \\
\mathrm{cm} .\end{array}$ & $\begin{array}{l}\text { Density } \\
\text { g.cm. }{ }^{-3}\end{array}$ & $\begin{array}{c}\text { Accumulation } \\
\text { g.cm. }\end{array}$ \\
\hline $195^{8}$ & $o-49$ & $0.39 \mathrm{I}$ & 19.2 \\
\hline I957 & $49^{-} 9^{2}$ & o. 395 & $17 \cdot 0$ \\
\hline 1956 & $9^{2-1} 44$ & 0.381 & 19.8 \\
\hline 1955 & I $44^{-1} 79$ & 0.417 & $14 \cdot 6$ \\
\hline I954 & $179-230$ & $0 \cdot 43^{8}$ & $22 \cdot 3$ \\
\hline I 953 & $230-269$ & 0.440 & $17 \cdot 2$ \\
\hline 1952 & $269-313$ & 0.444 & $19 \cdot 5$ \\
\hline $195^{1}$ & $313-34$ I & 0.444 & $12 \cdot 4$ \\
\hline 1950 & $34^{I-39^{I}}$ & o. 495 & $24 \cdot 8$ \\
\hline I 949 & $39^{I-429}$ & $0.5^{1}$ & 19.4 \\
\hline I948 & $429-464$ & $0.5^{\circ}$ & $17 \cdot 5$ \\
\hline 1947 & $464-495$ & $0 \cdot 49$ & $15 \cdot 2$ \\
\hline 1946 & $495-520$ & 0.53 & $13 \cdot 2$ \\
\hline 1945 & $5^{20}-55^{8}$ & 0.53 & $20 \cdot 1$ \\
\hline 1944 & $55^{8-57^{8}}$ & $0 \cdot 53$ & 10.6 \\
\hline 1943 & $578-622$ & $0 \cdot 5^{2}$ & $22 \cdot 9$ \\
\hline $194^{2}$ & $622-654$ & $0 \cdot 53$ & $17 \cdot 0$ \\
\hline I94 I & $654-680$ & $0 \cdot 54$ & I $4 \cdot 0$ \\
\hline $194^{\circ}$ & $680-720$ & $0 \cdot 55$ & $22 \cdot 0$ \\
\hline I939 & $720-746$ & $0 \cdot 5 \mathrm{I}$ & $13 \cdot 3$ \\
\hline $193^{8}$ & $746-794$ & $0 \cdot 5^{6}$ & $26 \cdot 9$ \\
\hline I937 & $794-84^{\circ}$ & $o \cdot 5^{8}$ & $26 \cdot 7$ \\
\hline 1936 & $840-868$ & $0 \cdot 57$ & I $6 \cdot 0$ \\
\hline 1935 & $868-896$ & o. 59 & I $6 \cdot 5$ \\
\hline 1934 & $896-93^{8}$ & 0.60 & $25 \cdot 2$ \\
\hline I933 & $93^{8}-9^{8} 4$ & $0 \cdot 63$ & $29 \cdot 0$ \\
\hline $193^{2}$ & $984-1008$ & 0.62 & I 4.9 \\
\hline $193^{1}$ & $1008-1040$ & $0 \cdot 60$ & $19 \cdot 2$ \\
\hline I930 & I 040-I 068 & 0.63 & $17 \cdot 6$ \\
\hline I929 & $1068-1086$ & 0.63 & I I 3 \\
\hline I 928 & $1086-1122$ & 0.64 & $23 \cdot 0$ \\
\hline 1927 & I $122-1160$ & 0.65 & $24 \cdot 7$ \\
\hline 1926 & I $160-1182$ & 0.64 & $14 \cdot I$ \\
\hline 1925 & 1 1 82-1 196 & 0.65 & $9 \cdot I$ \\
\hline 1924 & I 1 96-1216 & $0 \cdot 65$ & $13 \cdot 0$ \\
\hline 1923 & $1216-123^{2}$ & 0.65 & $10 \cdot 4$ \\
\hline 1922 & 1 $23^{2-1248}$ & 0.65 & 10.4 \\
\hline $19^{21}$ & I $24^{8-1264}$ & 0.68 & $10 \cdot 9$ \\
\hline 1920 & $1264-129^{2}$ & 0.68 & 19.0 \\
\hline I919 & $1292-1324$ & $0 \cdot 68$ & $2 \mathrm{I} \cdot 8$ \\
\hline 1918 & $13^{2} 4^{-1} 33^{8}$ & 0.68 & $9 \cdot 5$ \\
\hline I917 & I $33^{8}-13^{6} 4$ & $0 \cdot 69$ & $17 \cdot 9$ \\
\hline 1916 & $1364^{-1} 39^{\circ}$ & 0.65 & $16 \cdot 9$ \\
\hline $19^{15}$ & I $390-14$ I 2 & 0.69 & $15 \cdot 2$ \\
\hline 1914 & $1412-1436$ & 0.70 & $1 \overline{6} \cdot 8$ \\
\hline 1913 & 1 $43^{6-1} 47^{2}$ & 0.68 & $24 \cdot 5$ \\
\hline
\end{tabular}

For comparison, other values of the annual accumulation obtained near Scott Base are given: 
(i) Between January 1959 and February 1960 , over $60 \mathrm{~km}$. of the trail from Scott Base to "Little America", 18 g.cm. ${ }^{-2}$ (Stuart and Heine, I96r [a]).

(ii) For 1959, along the trail from Scott Base to the Skelton Glacier, 20 g.cm. ${ }^{-2}$ (Stuart and Heine, I96r [b]).

(iii) For the period I903 to I909, at Scott's depot "A", I4 km. east of Minna Bluff, I9 g.cm..$^{-2}$ (Wright and Priestley, I922).

\section{Movement of the Ige Shelf}

The movement of the ice shelf over various periods was determined at 40 points within $30 \mathrm{~km}$. of Scott Base. The stake positions are shown in Figures I, 3 and 4 and the movement vectors, extrapolated or interpolated to a one-year period, are listed in Table II.

\begin{tabular}{|c|c|c|c|}
\hline \multicolumn{2}{|c|}{ TABle II. Velocities anI } & $\begin{array}{l}\text { CTIONS OF Mo } \\
\text { F NEAR SCOTT }\end{array}$ & \\
\hline Station & $\begin{array}{l}\text { Velocity } \\
\text { m.yr. }{ }^{-1}\end{array}$ & $\begin{array}{l}\text { Direction in } \\
\text { which moving } \\
{ }^{\circ} \text { true }\end{array}$ & $\begin{array}{c}\text { Period of } \\
\text { observation } \\
\text { days }\end{array}$ \\
\hline \multicolumn{4}{|l|}{ Resection stations } \\
\hline $\begin{array}{l}86 \\
86 \mathrm{~A} \\
87 \\
89 \\
9^{1}\end{array}$ & $\begin{array}{l}863 \\
824 \\
585 \\
505 \\
688\end{array}$ & $\begin{array}{l}\text { о Iо } \\
\text { о07 } \\
\text { oo6 } \\
351 \\
169\end{array}$ & $\begin{array}{l}264 \\
264 \\
26 \mathrm{I} \\
268 \\
389\end{array}$ \\
\hline 93 & 181 & 289 & 388 \\
\hline 94 & 109 & 279 & 374 \\
\hline 104 & $23 \mathrm{I}$ & 307 & 345 \\
\hline 101 & 171 & 312 & 346 \\
\hline B-I & 18 & 259 & 190 \\
\hline B-2 & 20 & 263 & 190 \\
\hline B-3 & 22 & 268 & 190 \\
\hline \multicolumn{4}{|c|}{ Land-based triangulation stations } \\
\hline 2 & $9^{\mathrm{I}}$ & 270 & 315 \\
\hline 3 & 95 & 270 & $3^{15} 5$ \\
\hline 4 & 95 & 270 & 200 \\
\hline 6 & 106 & 270 & $3^{15}$ \\
\hline 7 & $9^{1}$ & 270 & $3^{15}$ \\
\hline 8 & 102 & 267 & 409 \\
\hline 10 & 102 & $265^{\prime}$ & 363 \\
\hline I 2 & го6 & 270 & $3^{15}$ \\
\hline I3 & $\mathrm{IO2}$ & 270 & 315 \\
\hline 14 & $\mathrm{II}_{3}$ & 270 & $9^{2}$ \\
\hline I6 & 95 & 268 & 94 \\
\hline 17 & 7 & 245 & 363 \\
\hline 18 & ${ }^{15}$ & 253 & 363 \\
\hline 19 & 22 & 253 & 248 \\
\hline 20 & 22 & $25^{8}$ & 363 \\
\hline $\begin{array}{l}27 \\
27\end{array}$ & $5^{8}$ & 270 & 363 \\
\hline 28 & 29 & 253 & 363 \\
\hline 34 & 73 & 275 & 195 \\
\hline 36 & 4 & 215 & 1 38 \\
\hline 37 & 11 & 230 & I95 \\
\hline 38 & 22 & $24^{2}$ & 14 \\
\hline 39 & $9^{1}$ & 277 & 14 \\
\hline $4^{\circ}$ & 84 & 277 & $3^{\dot{8}}$ \\
\hline $4^{2}$ & 84 & 275 & I95 \\
\hline 43 & 84 & 275 & 195 \\
\hline 44 & 139 & 302 & 138 \\
\hline 45 & 84 & 274 & I 38 \\
\hline rmohm site & 77 & 270 & 200 \\
\hline
\end{tabular}


The positions of most of the stakes close to land were determined by triangulation from well-surveyed points on land, whereas those of stakes on the trail to the Skelton Glacier and near White Island were determined by resection.

The probable errors in the calculated velocity and in the direction of motion are about $5 \mathrm{~m} . \mathrm{yr}^{-1}$ and $5^{\circ}$ for triangulated stations, and up to $3^{\circ} \mathrm{m} . \mathrm{yr}^{-1}$ and $10^{\circ}$ for the resected stations.

In the area east of the line from station 89 to Cape Crozier (stations 86, 86A, 87 and 89; Fig. I) the ice movement is northward. The velocities at the neighboring stations 86 and $86 \mathrm{~A}$

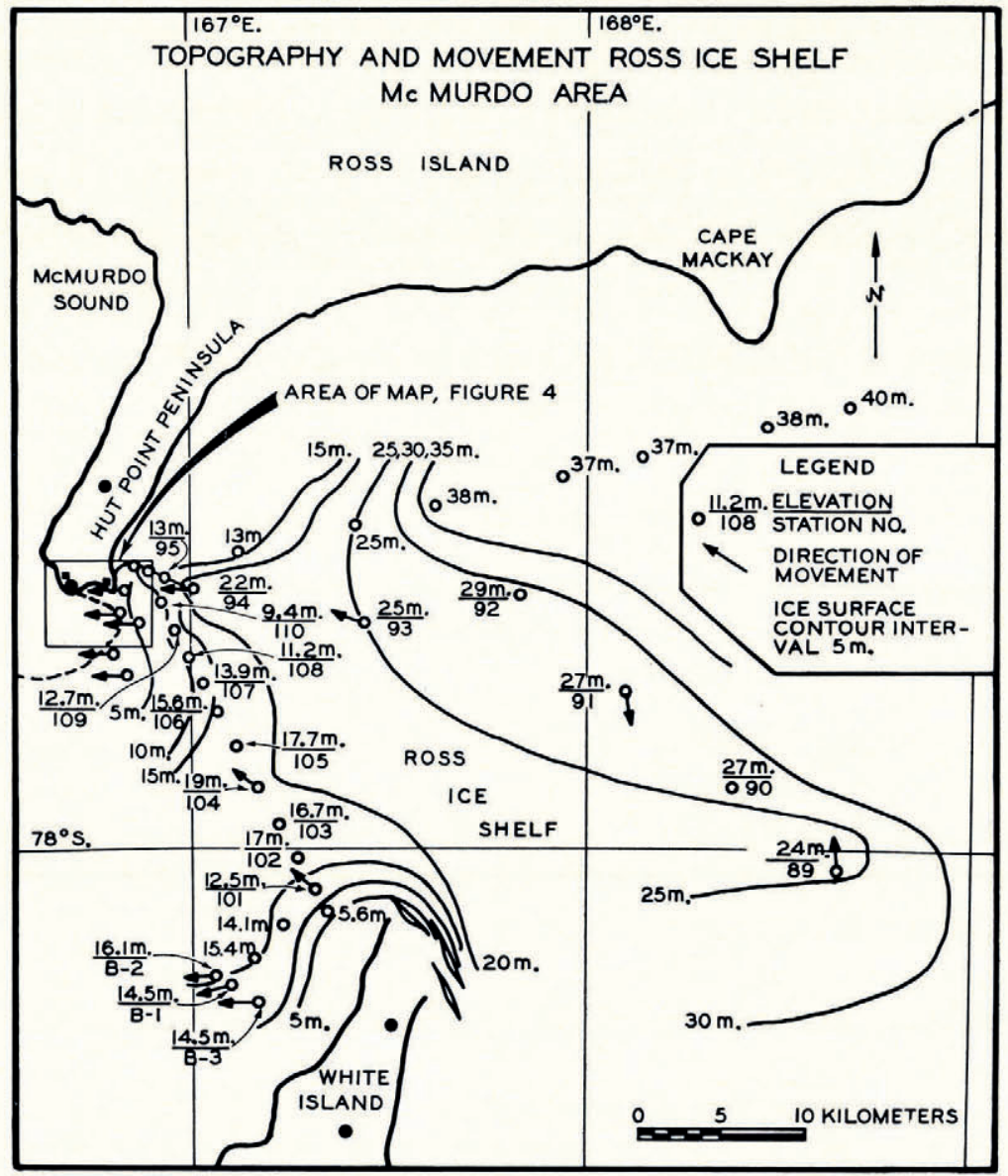

Fig. 3. Map of the Ross Ice Shelf between Ross Island and White Island, showing location of movement and ablation stations and topography of the ice surface

average 844 m.yr. ${ }^{-1}$, the highest yet measured on the Ross Ice Shelf. (However, Crary (196I [a]) has estimated an ice velocity west of Roosevelt Island as high as I,400 m.yr. ${ }^{-\mathbf{r}}$.) To the north-west of station 86 the velocity decreases, and at station 89 it is $505 \mathrm{~m} . \mathrm{yr} .^{-1}$.

The conditions in the transition zone appear to be complex and unfortunately only one value for the movement is available, namely that at station $9 \mathrm{r}$. This gives an apparently anomalous velocity of $688 \mathrm{~m} . y \mathrm{r}^{-\mathrm{I}}$ in a southerly direction. Crary (unpublished) reported that the ice thickness in the transition zone varies; for example, it is greater at station 92 than at 
stations 90 or 91. Series of pressure ridges in this zone converge on Cape Crozier (Fig. 2) and crevasses are present.

At the measured points in the eastern part of the "McMurdo Ice Shelf" the ice movement is westward or north-westwards. Twenty kilometers from Scott Base the velocity is about $200 \mathrm{~m} \cdot \mathrm{yr}^{-1}$ (stations 93, Ior and 104; Fig. 3), but closer to Scott Base it drops to about Ioo m.yr. ${ }^{-1}$ (in good agreement with velocities between $67 \cdot 5$ and $89 \cdot 1 \mathrm{~m} . y .^{-1}$ measured at 7 points by Macdonald and Hatherton ( $196 \mathrm{I})$ ). This velocity is maintained to the edge of the

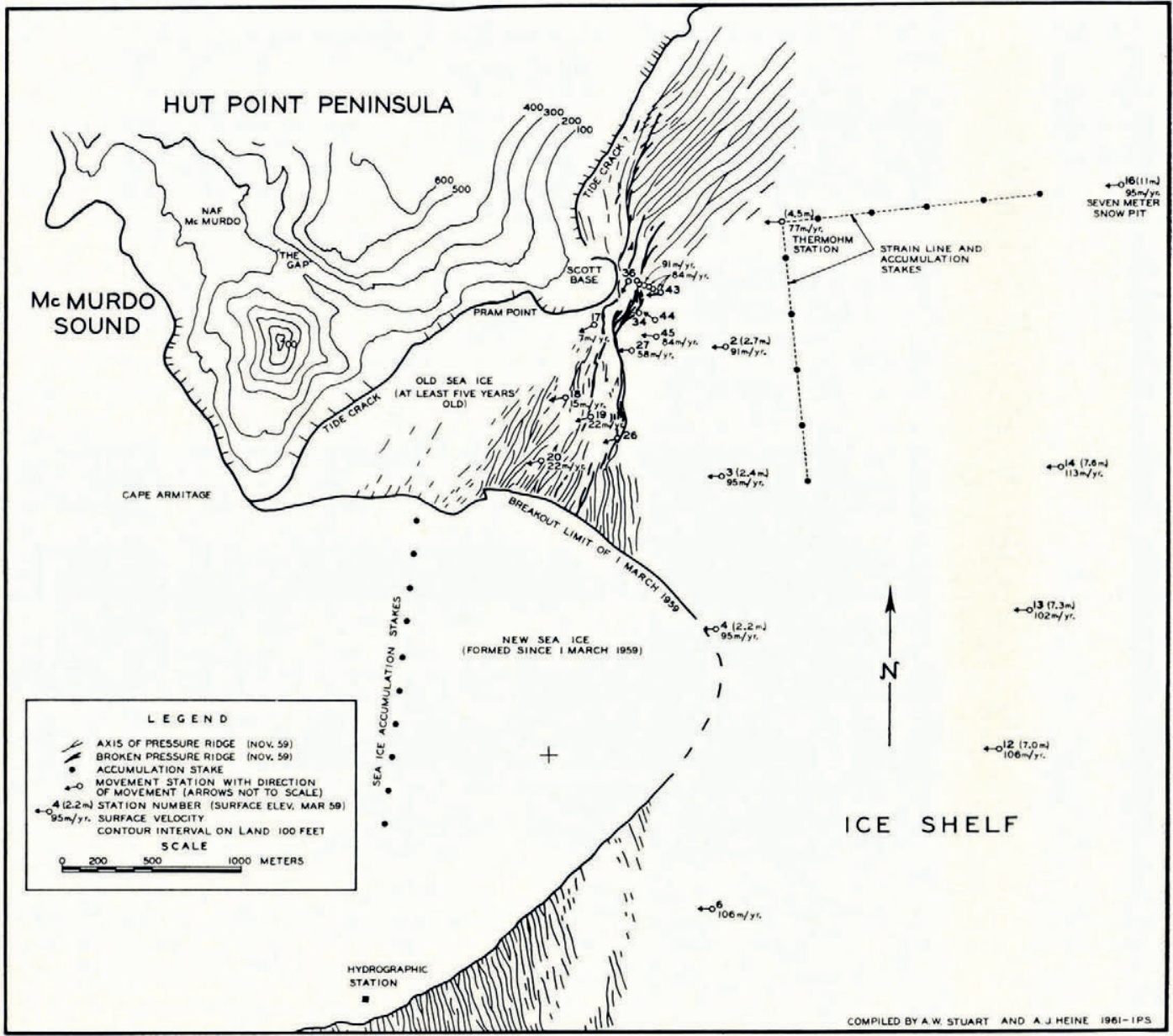

Fig. 4. Map of the ice shelf and land near Scott Base, showing station locations. (Based on U.S. Navy map NAF McMurdo H.O. 8 September 1960 , with additional information from U.S. Navy vertical aerial photographs oo $3-006 F-32$ VX-6 USN ${ }_{14}$ November 1959 and oblique aerial photographs oo $3-006$ F-3I VX-6 USN I 4 November 1959)

ice shelf except where it abuts Ross Island and the old sea ice between Cape Armitage and Pram Point. In the area of the pressure ridges, very close to Scott Base (Fig. 4), the velocity decreases rapidly westwards. At stations 39, 40, 42 and 43, east of the pressure ridges, the velocity is about $85 \mathrm{~m} . y$. $^{-1}$ while at stations 38,37 and 36 in the pressure ridges the velocity is much less, and is decreasing westwards, to $4 \mathrm{~m} . \mathrm{yr}^{-1}{ }^{-1}$ at station 36 . Furthermore, the direction of movement progressively changes from westwards, east of the ridges, to south-westwards at the closest station $(36)$ to Pram Point. 
The nature of the transition zone has not been fully determined. If the "McMurdo Ice Shelf" is merely a distributary of the main Ross Ice Shelf, then the transition zone is a shear zone associated with the blocking of the northward flow by Ross Island and the complex stress conditions which produce the change in flow direction. However, if a considerable part of the ice in the "McMurdo Ice Shelf" is obtained from Ross Island, the ridges in the transition zone may be largely the result of normal compression. The existing observations show southward movement at station $9 \mathrm{I}$, thinner ice in the transition zone on a line south-west from Scott Base, and ice thicker near Ross Island than $20 \mathrm{~km}$. farther south (Macdonald and Hatherton, r $96 \mathrm{r}$ ), but additional information is required on ice movement in the eastern part of "McMurdo Ice Shelf" and in the transition zone.



Fig. 5. Snow accumulation at stakes in the Scott Base area, 1959-6o

\section{Horizontal Strain of the Ice Shelf and Its Effect on Density}

Measurements of the surface horizontal strain rate were made near the thermohm site (Fig. 4). An L-shaped line was orientated so that one leg was parallel to the direction of movement (and of maximum strain) while the other was normal to it. Each leg was $\mathrm{I} \cdot 5 \mathrm{~km}$. long and was double-chained three times over a I2-month period. Parallel to the direction of movement the strain-rate was $-0.0076 \mathrm{yr}^{-1}$, while perpendicular to it the measured change in length was less than the measuring errors.

A second but less accurate value of the strain-rate is obtained by comparing the surface velocities at the thermohm station and at station 93 . Between these points the mean strainrate is $-0.007 \mathrm{I} \pm 0.0010 \mathrm{yr}^{-\mathrm{I}}$.

The sub-surface snow density at the $7 \mathrm{~m}$. pit site is higher than that reported at most polar sites having comparable values of accumulation and mean annual air temperature. Some representative density values (in $\mathrm{g} . \mathrm{cm} .^{-3}$ ) are as follows: 


\begin{tabular}{|c|c|c|c|c|c|c|c|c|}
\hline \multirow{3}{*}{ Depth } & \multicolumn{2}{|c|}{ GREENLAND } & \multicolumn{6}{|c|}{ Antarctica } \\
\hline & \multirow{3}{*}{ Site 2} & \multirow{3}{*}{ "Eismitte" } & \multirow{2}{*}{ Maudheim } & \multirow{3}{*}{$\begin{array}{c}\text { "Little } \\
\text { AmericaV" }\end{array}$} & \multicolumn{3}{|c|}{ "Camp Michigan" } & \multirow{3}{*}{$\begin{array}{l}\text { Scott } \\
\text { Base }\end{array}$} \\
\hline & & & & & Non- & Folded & Folded & \\
\hline & & & & & & & & \\
\hline & & & 0.488 & & 0.486 & $0.62-0.64$ & $o \cdot 69$ & $0.50-0.53$ \\
\hline 10 & $0 \cdot 4^{8-0} \cdot 5^{6}$ & 0.520 & 0.568 & $0.52-0.54$ & 0.562 & $0 \cdot 72$ & $0 \cdot 7^{2}$ & $0.61-0.63$ \\
\hline 15 & $o \cdot 45^{-0} \cdot 49$ & 0.560 & 0.620 & $0.57-0.58$ & 0.626 & & $0 \cdot 75$ & 0.69 \\
\hline
\end{tabular}

Values for "Little America V" are from Ragle and others (I960) and the remainder, except for Scott Base, are from Zumberge and others (1960). Densities at "South Ice" and Charcot are similar to those at "Eismitte" (Lorius, I962).
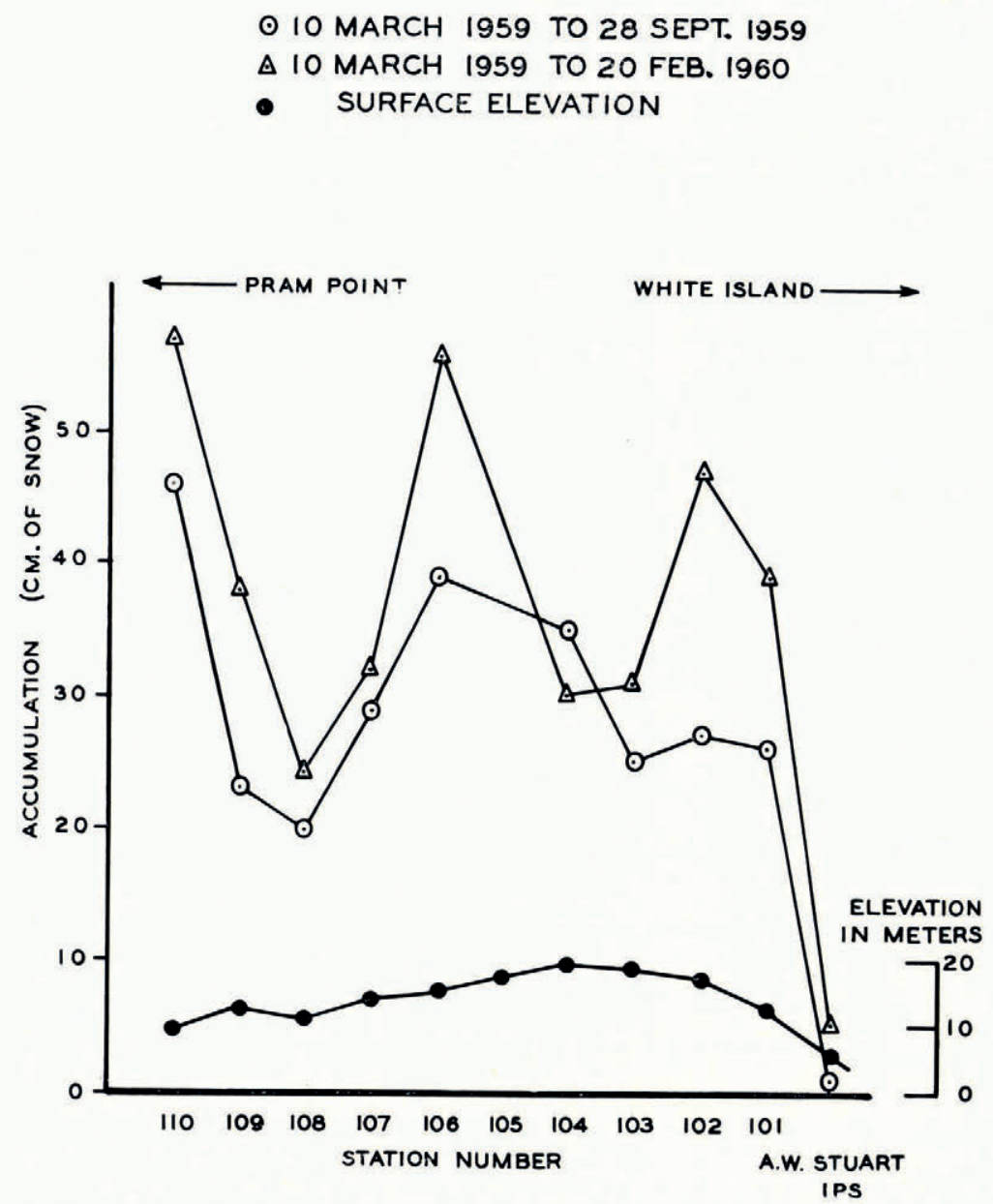

Fig. 6. Snow accumulation at stations between Pram Point and White Island, I959-6o

The high values at "Camp Michigan" have been attributed to horizontal compaction (Zumberge and others, 1960) but the stress pattern there is very complex and produces intensive folding. Theoretical treatment has not been attempted yet. Near the Scott Base $7 \mathrm{~m}$. pit the stress pattern appears to be simple and does not produce folding in the area of the pit. On glaciers a similar phenomenon can occur; Crary and Wilson (I96r) have shown that 
high densities on part of the Skelton Glacier are associated with negative horizontal strainrates.

The effect of horizontal compression on the variation of density with depth is best shown by comparing the Scott Base and "Little America V" data. The mean annual temperatures and snow accumulations are nearly the same at the two places, but the horizontal strain at "Little America V" is much less than that at Scott Base. Crary (196r [b]) reported horizontal

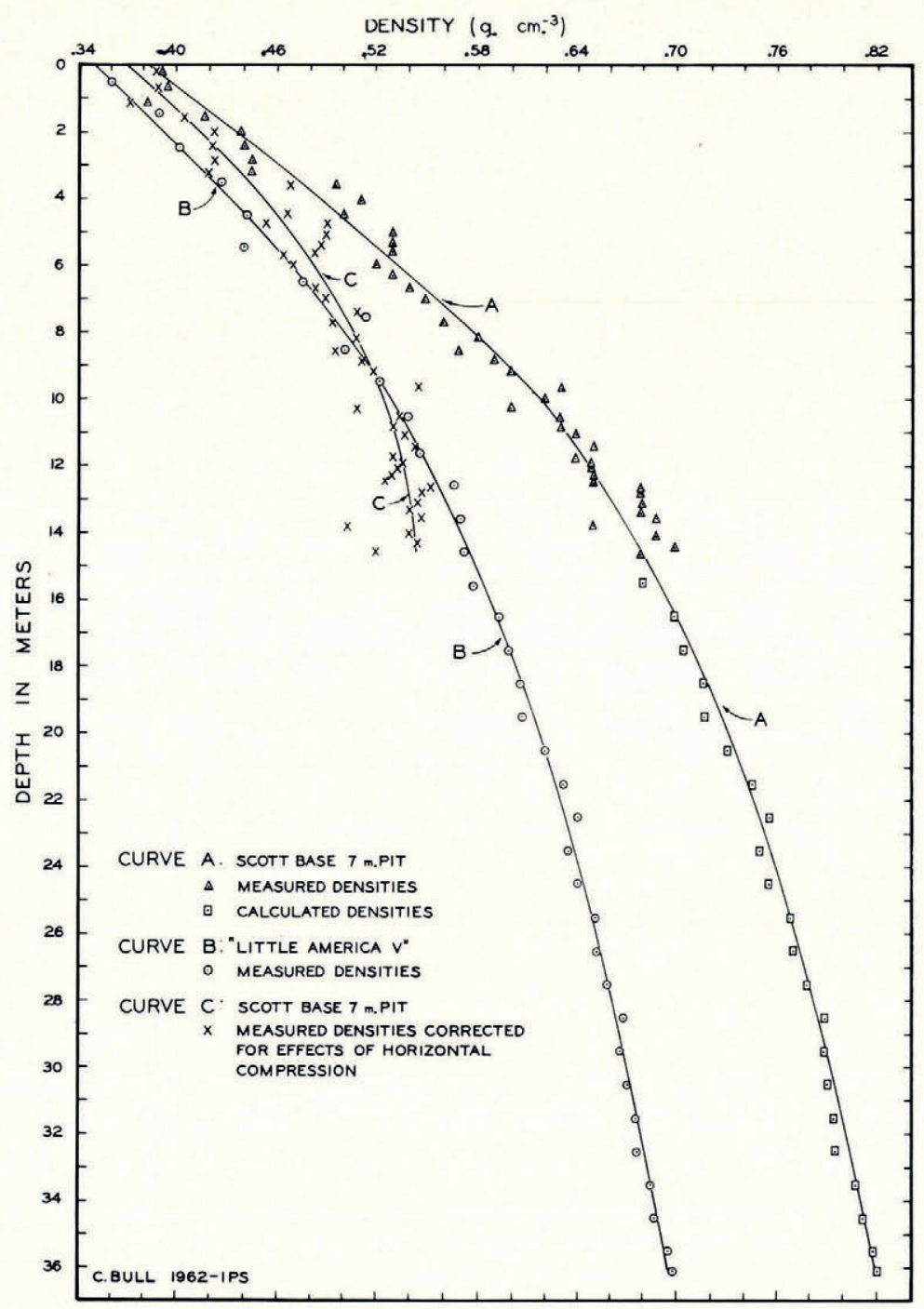

Fig. 7. Variation of snow densities with depth at Scott Base $7 \mathrm{~m}$. pit and at "Little America V"

extensive strain-rates of $0 \cdot 00129$ and $0 \cdot 0008 \mathrm{I} \mathrm{yr} .^{-1}$ normal and parallel to the direction of ice flow. The density values at Scott Base have been "corrected" for the effect of horizontal compression as follows. The effects of horizontal strain at "Little America" are ignored. It is assumed that the distribution of horizontal velocities on the ice shelf at Scott Base has remained unchanged for about $5^{\circ} \mathrm{yr}$. The snow now at a depth of $\mathrm{I}_{5} \mathrm{~m}$. in the pit was deposited $45 \mathrm{yr}$. 
ago on the surface east of the present station 93 . Since then it has been subjected to a mean strain-rate of $-0 \cdot 00735 \mathrm{yr}^{-\mathrm{I}}$. The snow near the surface in the pit has been subjected to a strain-rate of $-0 \cdot 0076 \mathrm{yr}^{-1}$ since it was deposited. It is assumed that the mean strain-rate to which the snow in the pit has been subjected varies linearly with its age beween these limits. Starting with a surface density of $0.39 \mathrm{I} \mathrm{g.cm.} .^{-3}$, the density increase per year due to the horizontal strain has been calculated and has been subtracted from the measured values. The original densities, the densities corrected in this way, and the densities at "Little America V" are compared in Figure 7. In view of the approximations involved, the agreement is good between the "corrected" Scott Base densities and those at "Little America". The discrepancies at depth may indicate that the strain-rate in the past was less than now, or that the decrease in strain-rate eastwards is greater than that given by the comparison of velocity at the pit with that at station 93. (See also the section below.) It is also possible that positive vertical strain-rates exist, with consequent vertical thickening of the ice shelf. Since no data are available, this possibility has not been considered further, but any thickening must be at a rate less than that of bottom melting.



Fig. 8

Infiltration of Brine into the Ice Shelf

In addition to the core to $15.42 \mathrm{~m}$. at the $7 \mathrm{~m}$. pit, another was drilled to $13.7 \mathrm{~m}$. at the thermohm station and shallower ones at stations 36 and 2 (Fig. 4). In all of the cores the firn was brine-soaked below a certain level; the slush in the two deeper holes prevented deeper drilling by hand. Measurements of salinity were made at intervals along the cores.

At stations 36 and 2 brine was encountered approximately at sea-level; at the thermohm site at a depth of $5.26 \mathrm{~m}$. (approximately $0.7 \mathrm{~m}$. below sea-level) and at the $7 \mathrm{~m}$. pit at a depth of $\mathrm{I}_{5} \cdot \mathrm{IO} \mathrm{m}$. (4. I m. below sea-level). Brine-soaking continued from these depths to the bottom of all the holes. Figure 8 represents the situation. 
It is clear that the material near the bottom of these holes is brine-soaked firn and not sea ice. At a depth of ${ }_{15} \cdot{ }_{1} 8-15.30 \mathrm{~m}$. at the $7 \mathrm{~m}$. pit site the density is $0.7 \mathrm{I} \mathrm{g} . \mathrm{cm} .^{-3}$ and the salinity is $20 \%$. These values would be most unusual for sea ice. Furthermore, no difference in the fabric is found between the soaked and the neighboring dry firn.

Brine is also found in the Ward Hunt Ice Shelf (Ellesmere Island) (Marshall, I96o; Lyons and Leavitt, I96I) and in the Lazarev Ice Shelf, but not at "Little America V", Maudheim (Schytt, I958 [a], [b], I96o) or "Ellsworth" (Neuberg and others, I959).

The mechanisms by which brine-soaking of the ice shelf can occur appear to be (a) vertical infiltration from the bottom, (b) lateral infiltration from the seaward edge, and (c) diffusion along crystal boundaries.

The diffusion method has been suggested for the Ward Hunt Ice Shelf by Marshall ( 1960 ), but the vertical transport of salt may be assisted by surface ablation and freezing at the bottom of the ice shelf. However, the absence of brine at all depths in the ice shelves at Maudheim, "Little America" and "Ellsworth" indicate that this is not a widespread process in Antarctica. Diffusion of salt solution is likely to be a slow process; bottom melting may proceed faster. At "Little America" bottom melting removes annually about $80 \mathrm{~cm}$. of ice (73 g.cm..$^{-2}$ ). Near Scott Base the bottom melting is comparable, so that the soaking there is not likely to be due to diffusion.

Because lateral and vertical infiltration can occur only in firn with interconnected pore spaces, the firn at sea-level at the ice shelf edge or at the bottom of the ice shelf must be permeable. For air the transition from permeable (firn) to impermeable (ice) occurs at a density of about $0.8 \mathrm{I} \mathrm{g.cm.} .^{-3}$, and in the absence of specific data it is assumed that the same critical density applies for permeability to brine.

At "Little America V" and at Maudheim this initial condition is met for lateral infiltration. At both places the density at sea-level is about $0 \cdot 76$ g.cm. ${ }^{-3}$ (Schytt, I958 [a], [b], I96o; Ragle and others, I960; Crary, I96r [a]). In both areas the elevation of the ice shelf edge is less than it is at the drill site, so that the densities at sea-level at the edge should be less than $0 \cdot 76$ g.cm. ${ }^{-3}$.

Two other factors influence lateral infiltration: (a) the temperature, and (b) the forward velocity of the ice shelf. In the hole at "Little America V" the temperature at $7 \mathrm{~m}$. below sea-level is $-22 \cdot 3^{\circ} \mathrm{C}$., which is lower than the cryohydric point of salt water. At Maudheim the temperature at all depths is higher than $-18^{\circ} \mathrm{C}$. but the ice shelf is estimated to be breaking away at about 280 m.yr. ${ }^{-1}$ (Swithinbank, I 957 [a], [b], I958) which may be greater than the velocity of lateral infiltration.

The density at the ice shelf bottom is the controlling factor in the vertical infiltration mechanism; the horizontal movement of the ice shelf and the temperature in the ice shelf can only limit the vertical extent of infiltration. Because the ice-water contact must be at about $-2^{\circ} \mathrm{C}$., some penetration occurs even in fast-moving ice as long as the bottom is permeable.

At "Little America V", Maudheim and "Ellsworth", the density at the ice shelf bottom is more than $0.8 \mathrm{I} \mathrm{g} . \mathrm{cm} .^{-3}$, which should preclude vertical infiltration. Near Scott Base the bottom densities have not been measured directly and it is difficult to estimate them accurately because the densities in the upper layers are abnormally high.

An estimate of the bottom density at the $7 \mathrm{~m}$. pit site is obtained as follows: the difference between the densities at "Little America V" and at Scott Base for given depths is listed in Table III as a percentage of the density at that depth at "Little America V". In the o-5 m. range the Scott Base density is 9.3 per cent higher, in the $5^{-10} \mathrm{~m}$. range $15^{\circ} \mathrm{o}$ per cent and in the $10-15 \mathrm{~m}$. range 17.7 per cent higher than the corresponding densities at "Little America". More annual layers (19) occur between io and $15 \mathrm{~m}$. depth than between 5 and ro $\mathrm{m}$. ( $\mathrm{I}_{5}$ ) or between o and $5 \mathrm{~m}$. ( $\mathrm{I}_{3}$ ). If the increase in density due to horizontal compaction were independent of density, the disparity between the Scott Base and "Little America V" densities would increase with depth faster than linearly. In fact, the disparity increases only 
from 15 per cent in the $5^{-10} \mathrm{~m}$. range to $17 \cdot 7$ per cent at $10-15 \mathrm{~m}$. It is therefore reasonable to assume that at greater depths the per cent density difference between the two profiles asymptotically approaches a constant value of about 20 per cent. (If the ice shelves were of greater thickness, so that the densities approached more closely that of pure ice, the percentage difference between the two profiles would decrease with depth and eventually disappear, since the densities at both places would reach the same value asymptotically.) With this assumption, of constant percentage difference between the densities at a given depth at "Little America" and Scott Base, the densities at the Scott Base site at depths greater than $15 \mathrm{~m}$. have been estimated from the "Little America" data. The density should reach the critical value of $0.8 \mathrm{I} \mathrm{g.cm} .^{-3}$ at between 33 and $34 \mathrm{~m}$. The thickness of the ice shelf at the pit site is $32 \pm$ $2 \mathrm{~m}$. (see p. 412); therefore, the bottom density should be low enough to permit vertical brine infiltration.

Table III. Comparison of Snow Densities at "Little America V" and Scott Base

Columns 2 and 3 give mean densities, in g.cm. ${ }^{-3}$, over $1 \mathrm{~m}$. depth increments. In columns 5 and 6 the difference between the densities is given as a percentage of the density at "Little America V".

\begin{tabular}{|c|c|c|c|c|c|}
\hline Depth & $\begin{array}{c}\text { "Little } \\
\text { America V" }\end{array}$ & $\begin{array}{l}\text { Scott } \\
\text { Base }\end{array}$ & Difference & Difference & $\begin{array}{l}\text { Mean difference } \\
\text { over } 5 \mathrm{~m} \text {. depth } \\
\text { intervals }\end{array}$ \\
\hline $\mathrm{m}$. & g. $\mathrm{cm} \cdot{ }^{-3}$ & g.cm..$^{-3}$ & & per cent & per cent \\
\hline $0-I$ & $0 \cdot 360$ & $0 \cdot 393$ & 0.033 & $9 \cdot 2$ & \\
\hline $\mathrm{I}-2$ & $0 \cdot 390$ & $0 \cdot 402$ & 0.012 & $3 \cdot I$ & \\
\hline $2-3$ & 0.402 & 0.446 & 0.044 & 10.9 & \\
\hline $3-4$ & $0 \cdot 4^{26}$ & 0.469 & 0.043 & 10.1 & \\
\hline $4-5$ & $0 \cdot 44^{2}$ & 0.50 & $0.05^{8}$ & I $3 \cdot \mathrm{I}$ & $9 \cdot 3$ \\
\hline $5^{-6}$ & $0 \cdot 44^{\mathrm{I}}$ & o. 53 & o. 089 & $20 \cdot \mathrm{I}$ & \\
\hline $6-7$ & 0.476 & o. 55 & 0.074 & 15.5 & \\
\hline $7-8$ & 0.515 & 0.55 & 0.035 & $6 \cdot 8$ & \\
\hline $8-9$ & 0.501 & 0.57 & 0.069 & I 3.8 & \\
\hline $9^{-10}$ & $0 \cdot 5^{22}$ & 0.62 & $0 \cdot 09^{8}$ & 18.8 & ${ }^{1} 5.0$ \\
\hline IO-II & $0.54^{1}$ & 0.62 & 0.079 & 14.6 & \\
\hline I I -12 & $0.54^{8}$ & 0.65 & $0 \cdot 102$ & I 8.6 & \\
\hline $12-13$ & 0.569 & 0.67 & $0 \cdot$ IOI & $17 \cdot 8$ & \\
\hline $13^{-14}$ & 0.572 & 0.67 & o.og 8 & $17 \cdot 1$ & \\
\hline $14^{-1} 5$ & 0.574 & 0.69 & o. I I 6 & $20 \cdot 2$ & $17 \cdot 7$ \\
\hline
\end{tabular}

East of the pit site where the ice shelf thickens appreciably the bottom density should exceed $0.8 \mathrm{r}$ g.cm. ${ }^{-3}$. A critical evaluation of the possible mechanisms of soaking could easily be made by examining cores from sites east of the $7 \mathrm{~m}$. pit. If these cores were found to be brine-soaked, lateral infiltration would have to be the mechanism responsible. At present we can only report that at Maudheim, where lateral infiltration could have occurred, it has not, while at Scott Base, where either lateral or vertical infiltration could have occurred, the firn is soaked. The evidence, though not conclusive, strongly suggests that vertical infiltration is responsible for the soaking at Scott Base.

Apart from the "McMurdo Ice Shelf" and a small "ice shelf" near Wilkes Station, mentioned below, the only reported occurrence of brine soaking in shelf ice in Antarctica is near "Lazarev Station" (Dubrovin, I960). At a position $1 \cdot 3 \mathrm{~km}$. from the edge of the ice shelf brine was found at a depth of $4 \mathrm{I} \mathrm{m}$., $\mathrm{I} 8 \mathrm{~m}$. below sea-level, at a temperature of $-\mathrm{r} 3.5^{\circ} \mathrm{C}$. Pumping tests show that the brine in the hole was part of a larger supply which could move readily through the firn. Vertical infiltration is unlikely here because the ice shelf is about $140 \mathrm{~m}$. thick and must have a bottom density greater than $0 \cdot 8 \mathrm{I}$ g.cm. ${ }^{-3}$. Apparently this situation contradicts the postulates given above. Horizontal ice velocities were not reported. 
The Thickness of the Ice Shelf

Because it was not possible to drill by hand to the bottom of the ice shelf at the pit site and because the ice is too thin to permit the use of seismic methods, the thickness can be determined only approximately.

The surface elevation, determined by carefully controlled altimetry, was $\mathrm{I} \mathrm{I} \cdot \mathrm{O} \pm 0.5 \mathrm{~m}$. and the density of sea-water at the ice edge was $I^{\prime} \cdot 0260$ g.cm. ${ }^{-3}$ (Van der Hoeven, unpublished). With an i $\mathrm{m}$. surface elevation, freely floating ice shelves of the following thicknesses would have the stated mean densities: $34 \mathrm{~m} ., 0.69^{2} \mathrm{~g} . \mathrm{cm} .^{-3} ; 3^{2} \mathrm{~m} ., 0 \cdot 673$ g.cm..$^{-3}$; $30 \mathrm{~m} ., 0.650$ g.cm. ${ }^{-3} ; 28 \mathrm{~m}$., 0.623 g.cm. ${ }^{-3}$. With an II $5 \mathrm{~m}$. surface elevation the mean density for a $32 \mathrm{~m}$. thickness is $0.657 \mathrm{~g} . \mathrm{cm} .^{-3}$. Accepting the densities at depth obtained by the extrapolation method given above, the mean density of a $32 \mathrm{~m}$. thick shelf is $0.667 \mathrm{~g} . \mathrm{cm} \cdot{ }^{-3}$.

The mean annual temperature is known to $15 \mathrm{~m}$. depth and the ice-sea-water contact may be assumed to be $-\mathrm{I} \cdot 9^{\circ} \mathrm{C}$. Assuming that the temperature gradient varies with proportion of total distance through the ice shelf as it does at "Little America V" or at Maudheim, the extrapolated temperature reaches $-\mathrm{I} \cdot 9^{\circ} \mathrm{C}$. at about $3^{2} \mathrm{~m}$. It is appreciated that an accurate treatment of temperature distribution, taking the bottom melting into account, should be possible by the method outlined by Crary (ig6I [b]) but this requires a knowledge of the thermal diffusivity at all depths. The effect of freely moving brine on the thermal diffusivity of firn is not known. (Crary used this method to estimate bottom melting. Since the amount of bottom melting near Scott Base can be estimated from the surface profile, a temperature profile through the brine-soaked ice shelf would be valuable chiefly in determining diffusivities.)

\section{Bottom Melting}

The "McMurdo Ice Shelf" thins towards its seaward edge. Of the three possible mechanisms, surface ablation, lateral spreading and bottom ablation, the first two disagree with the observations quoted.

Between stations 93 and 94 (where the bottom is impermeable ice) the ice shelf thins at about $44 \mathrm{~g} . \mathrm{cm} \cdot \cdot^{-2} \mathrm{yr} \cdot{ }^{-1}$. Between the $7 \mathrm{~m}$. pit and thermohm sites the rate is $73 \mathrm{~g} \cdot \mathrm{cm} \cdot{ }^{-2} \mathrm{yr} \cdot{ }^{-1}$ (Macdonald and Hatherton (I96I) obtained a rate of $0.7 \mathrm{~m}$. of ice per year, from limited data). Nearer the edge, and in the bay ice between Cape Armitage and Pram Point, the rate of bottom melting must be less, and in the bay it is probably nearly equal to the annual surface accumulation.

The brine soaking of the firn greatly assists the bottom ablation process. The brine probably loosens the ice crystals by solution until the firn forms a slush which can be removed even by a weak water current. The lower strength of the brine-soaked firn at Scott Base has been noted, and is in agreement with the observations on a small static "ice shelf" near Wilkes Station (Hollin and others, I96r) where it was found that the soaked firn became less competent with increasing depth. To substantiate this conjecture, rates of bottom melting are required in dense sea ice of comparable thickness.

Observations during the winter of 1959 by Van der Hoeven (unpublished) at a site $5 \mathrm{~km}$. south-west of Scott Base (Fig. 4) show (a) that sea currents averaging about $20{\mathrm{~cm} . \mathrm{sec} .^{-1}}^{-1}$ change direction diurnally with a mean current from the east of $7 \cdot 5 \mathrm{~cm} . \mathrm{sec}^{-1}$, in contrast to the anti-clockwise current around Ross Island, previously postulated (Macdonald and Hatherton, I96r), (b) that the water is isothermal to $275 \mathrm{~m}$. (in a total depth of $580 \mathrm{~m}$.), and (c) that the temperature and salinity changed from $-\mathrm{r} \cdot 76^{\circ} \mathrm{C}$. and $34 \cdot 6 \%$ in May to $-\mathrm{I} \cdot 90^{\circ} \mathrm{C}$. and $34 \cdot 8 \%$ in August. Order of magnitude calculations show that to account for the bottom melting and the heat flow through the ice shelf, each vertical column of water of I $\mathrm{cm}^{2}$ cross-section must lose about roo cal. between its introduction under the ice shelf, assumed to be east of Cape Crozier, and its emergence in McMurdo Sound. The corresponding decrease in temperature in the well-mixed isothermal layer would be much less than $\mathrm{o}^{\circ} \mathrm{or}^{\circ} \mathrm{C}$. 
It thus seems entirely reasonable to attribute the thinning of the "McMurdo Ice Shelf" to this westward-flowing current.

\section{The Western Part of the "MaMurdo Ice Shelf"}

West of a line between the summit of White Island and Cape Armitage the ice shelf surface is ablating. The easternmost evidence of surface ablation was found in March I959, a few kilometers south-west of station iог, where small surface melt holes appeared. These increased in size westwards and $7 \mathrm{~km}$. west of station IO I many were $2 \mathrm{~m}$. deep and up to Io $\mathrm{m}$. long. In the walls of these holes the stratigraphy was composed largely of superimposed ice interlayered with dirt bands. In September I959 all of the holes had filled with drifting snow.

Several observations of surface ablation farther west have been recorded in the area of the Dailey Islands (lat. $77^{\circ} 52^{\prime}$ S., long. $165^{\circ}$ I $8^{\prime}$ E.) (Debenham, I920; Swithinbank and others, I96I). It has been suggested that in this area the "McMurdo Ice Shelf" is maintained by freezing of sea-water onto its bottom, while the surface is ablating. Recent observations on the Ward Hunt Ice Shelf (personal communication from H. Lister, May i962) confirm carlier suggestions that this ice shelf is nourished by bottom freezing. Nevertheless, the data given above and by Crary show that the main part of the Ross Ice Shelf is maintained by surface accumulation, and that bottom melting occurs, certainly near its northern edge and almost certainly over the rest of its area.

The reason for the change in conditions from surface accumulation near Scott Base to surface ablation near White Island is not known with certainty but it is now generally believed to be due to the presence of dust and moraine on the surface (from the land immediately to the south) which lowers the albedo. However, the figures given above (Fig. 6) show that even the winter surface accumulation is much less near White Island than near Pram Point.

It may be significant that the surface velocity in the ablating area (B-I, B-2 and B-3) is I $8 \mathrm{~m} . y r^{-1}$ to the west, while nearby in the accumulating area (station IOI) it is $7 \mathrm{I} \mathrm{m.yr} .^{-1}$ to the north-west (Fig. 3). Temperature profiles, salinity and density values through the ice shelf here are required for comparison with those on the Ward Hunt Ice Shelf of Ellesmere Island and in the bottom-melting areas of the "McMurdo Ice Shelf".

\section{Acknowledgements}

It is a pleasure to thank Mr. A. J. Heine for his assistance in the field and in the office. Mr. F. G. Van der Hoeven also assisted with the field work. Members of the Institute have helped in various ways. In particular, thanks are extended to Dr. F. Loewe for reading the manuscript. This work has been supported by National Science Foundation grants G-I48I 8 and G-20473.

MS. received 24 July 1962

\section{REFERENCES}

Crary, A. P. Unpublished. Preliminary ice thickness and water depth values. Victoria Land traverse memoran dum, no. 9. [Written 1959. See also Macdonald and Hatherton, i96r.]

Crary, A. P. 196 I [a]. Glaciological studies at Little America Station, Antarctica, 1957 and i 958. IG Y Glaciological Report Series (New York, IGY World Data Center A, Glaciology, American Geographical Society), No. 5.

Crary, A. P. I96r [b]. Glaciological regime at Little America Station, Antarctica. Fournal of Geophysical Research, Vol. 66 , No. 3 , p. $871-78$.

Crary, A. P., and Wilson, C. R. I96r. Formation of "blue" glacier ice by horizontal compressive forces. Fournal of Glaciology, Vol. 3, No. 30, p. 1045-50.

Debenham, F. 1920. A new mode of transportation by ice. Quarterly Fournal of the Geological Society of London, Vol. 75 , Pt. 2, p. $5^{\mathrm{I}-76}$. 
Dubrovin, L. I. 1960. Rassol v shel'fovom lednike Lazareva [Brine in the Lazarev Ice Shelf]. Informatsionnyy Byulleten' Sovetskoy Antarkticheskoy Ekspeditsii [Information Bulletin of the Soviet Antarctic Expedition], No. 22, p. $5^{-16}$. [Read in English translation.]

Hollin, J. T., and others. I961. Wilkes Station glaciology, 1958, by J. T. Hollin, C. Cronk and R. Robertson. Ohio State University Research Foundation. Report 825-2-Part X.

Lorius, C. J. 1962. Contribution to the knowledge of the Antarctic Ice Sheet: a synthesis of glaciological measurements in Terre Adélie. Fournal of Glaciology, Vol. 4, No. 31, p. 79-92.

Lyons, J. B., and Leavitt, F. G. 1961. Structural and stratigraphic studies on the Ward Hunt Ice Shelf. Bedford, Mass., Geophysics Research Directorate, U.S. Air Force Cambridge Research Center. (Report on contract AF 19/604-6188.)

Macdonald, W. J. P., and Hatherton, T. 1961. Movement of the Ross Ice Shelf near Scott Base. Fournal of Glaciology, Vol. 3, No. 29, p. 859-66.

Marshall, W. E. 1960. Structure and stratigraphy of T-3 and the Ellesmere Ice Shelf. (In Bushnell, V. C., $e d$. Scientific studies at Fletcher's ice island, T-3, 1952-1955. Vol. 3. Bedford, Mass., Geophysics Research Directorate, U.S. Air Force Cambridge Research Center, p. 45-78. (Geophysical Research Paper No. 63.))

Neuberg, H. A. C., and others. 1959. The Filchner Ice Shelf, by H. A. C. Neuberg, E. Thiel, P. T. Walker, J. D. Behrendt and N. B. Aughenbaugh. Annals of the Association of American Geographers, Vol. 49, No. 2, p. $110-19$.

Ragle, R. H., and others. I96o. Deep core drilling in the Ross Ice Shelf, Little America V, Antarctica, by R. H. Ragle, B. L. Hansen, A. J. Gow and R. W. Patenaude. U.S. Snow, Ice and Permafrost Research Establishment. Technical Report 70.

Schytt, V. $195^{8}$ [a]. Glaciology. II. Snow studies at Maudheim. Norwegian-British-Swedish Antarctic Expedition, 1949-52. Scientific Results (Oslo, Norsk Polarinstitutt), Vol. 4, A, p. 1-64.

Schytt, V. 1958 [b]. Glaciology. II. The inner structure of the ice shelf at Maudheim as shown by core drilling. Norwegian-British-Swedish Antarctic Expedition, 1949-52. Scientific Results (Oslo, Norsk Polarinstitutt), Vol. 4, C,

p. I $13-52$.
Schytt, V. 1960 . Glaciology. II. Snow and ice temperatures in Dronning Maud Land. Norwegian-British-Swedish Antarctic Expedition, 1949-52. Scientific Results (Oslo, Norsk Polarinstitutt), Vol. 4, D, p. I53-79.

Stuart, A. W., and Heine, A. J. I96 1 [a]. Glaciology, Victoria Land traverse, 1959-6o. Ohio State University Research Foundation. Report 968 , Part I.

Stuart, A. W., and Heine, A. J. 1961 [b]. Glaciological work of the 1959-6o U.S. Victoria Land traverse. Fournal of Glaciology, Vol. 3, No. 30, p. 997-1002.

Swithinbank, C. W. M. 1957 [a]. Glaciology. I. The morphology of the ice shelves of western Dronning Maud Land. Norwegian-British-Swedish Antarctic Expedition, 1949-52. Scientific Results (Oslo, Norsk Polarinstitutt), Vol. 3, A, p. I-37.

Swithinbank, C. W. M. 1957 [b]. Glaciology. I. The regime of the ice shelf at Maudheim as shown by stake measurements. Norwegian-British-Swedish Antarctic Expedition, 1949-52. Scientific Results (Oslo, Norsk Polarinstitutt), Vol. 3, B, p. $4^{\mathrm{I}-75}$.

Swithinbank, C. W. M. 1958. Glaciology. I. The movement of the ice shelf at Maudheim. Norwegian-BritishSwedish Antarctic Expedition, 1949-52. Scientific Results (Oslo, Norsk Polarinstitutt), Vol. 3, C, p. 77-96.

Swithinbank, C. W. M., and others. 1961. Faunal remains on an Antarctic ice shelf, by C. W. M. Swithinbank, D. G. Darby and D. E. Wohlschlag. Science, Vol. 1 33 , No. 3455 , p. 764-66.

Van der Hoeven, F. G. Unpublished. Ocean currents in McMurdo Sound, Antarctica, winter 1959. [Memorandum, University of Wisconsin, 1960.]

Wright, C. S., and Priestley, R. E. 1922. Glaciology. London, Harrison. (British (Terra Nova) Antarctic Expedition, rgio-1913.)

Zumberge, J. H., and others. 1960. Deformation of the Ross Ice Shelf near the Bay of Whales, Antarctica, by J. H. Zumberge, M. B. Giovinetto, R. Kehle and J. Reid. IGY Glaciological Report Series (New York, IGY World Data Center A, Glaciology, American Geographical Society), No. 3. 